\title{
Morphological specification of Chinianella scheympflugi HOFMANN, 1994, a Late Jurassic (?Earliest Cretaceous) dasycladalean alga of the western Tethyan domain
}

\author{
Felix SCHLAGINTWEIT \\ Lerchenauerstr. 167, 80935 München, Germany
}

Received September 2010; accepted November 2010

Available online 15 November 2010

DOI: $10.5038 / 1937-8602.56 .1 .1$

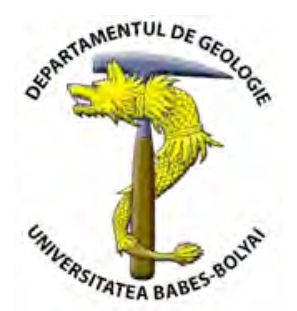

\begin{abstract}
The dasycladalean alga Chinianella? scheympflugi was described by Hofmann (1994) from the Tithonian of the Ernstbrunn Limestone of Lower Austria. This alga, so far unreported besides its type-locality, is reported from the Late Jurassic of Poland, the Northern Calcareous Alps of Austria, Crimea (Ukraine), and Greece (Parnassos Zone). Facies are well-agitated outer platform habitats (perireefal and back-reefal facies). The cylindrical thallus consists of three parts: a sterile Salpingoporellalike basal part (stalk), a fertile Chinianella-type main portion and a short sterile top part. The transition from the stalk to the main thallus portion is well marked and abrupt. The stratigraphic range of Chinianella? scheympflugi can be indicated as (Late) Kimmeridgian-Tithonian (?Early Berriasian).
\end{abstract}

Key words: Calcareous algae, systematic, Late Jurassic, western Tethys.

\section{INTRODUCTION}

In 1994, Hofmann described the new dasycladalean alga Chinianella? scheympflugi from the Tithonian Ernstbrunn Limestone of Lower Austria. With only 4 figures in the original publication, its morphological variability (e.g., biometric ranges of dimensions) was insufficiently known. It is worth mentioning that the quarries of the Ernstbrunn Limestone in Lower Austria also represent the type area of another dasycladale, Petrascula piai BACHMAYER, 1941. To date, Chinianella? scheympflugi has not been reported from any other location. It is here described from thinsections of the Late Jurassic Plassen Carbonate Platform of Austria supplemented by material from the Late Jurassic (?Earliest Cretaceous) of the Crimea Mountains/Ukraine (Fig. 1).

\section{MATERIAL AND SAMPLE LOCALITIES}

Northern Calcareous Alps of Austria: The Late Jurassic shallow-water evolution of the Northern Calcareous Alps is known as Plassen Carbonate Platform (PCP) (see Gawlick et al., 2009 for details). Chinianella? scheympflugi was found in various localities of the PCP (in alphabetical order): Mount Lärchberghörndl (e.g., Dya, 1992), Mount Litzelkogel (e.g., Schlagintweit, 2005), Mount Plassen (e.g., Schlagintweit et al., 2005), and Mount Rettenstein (e.g., Auer et al., 2009). Occasionally it can be found resedimented in basinal series of the Sillenkopf Formation (Missoni et al., 2001).

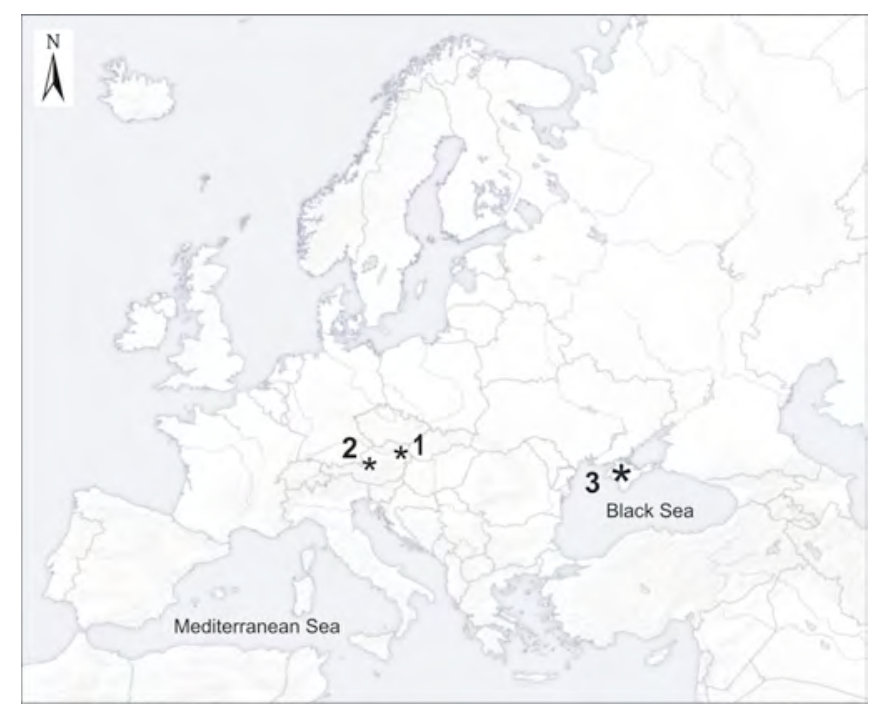

Fig. 1. Simple geographic map of Europe showing the type-locality of Chinianella scheympflugi HOFMANN, the Ernstbrunn Limestone of Lower Austria (1), the occurrence in the Plassen Carbonate Platform (here: type-locality Mount Plassen, Austria) (2), and the Crimea Mountains, Ukraine (3).

At Mount Plassen, the species was not treated in the framework of the taxonomic inventory by Schlagintweit et al. (2005); here it rarely occurs in the Latest Kimmeridgian- 
Earliest Tithonian high-energy, back-reefal to open lagoonal limestones together with rivulariacean-type and protohalimedacean algae (genus Pinnatiporidium). In nearreefal limestones, it is often associated with Petrascula bursiformis (Ettalon), Salpingoporella pygmaea (Gümbel) and the encrusting foraminifer Coscinophragma aff. cribrosa (Reuss). The occurrences at Mount Rettenstein can be ascribed to the Kimmerdigian, the exact age of the occurrence at Mount Lärchberghörndl is unknown, roughly Kimmeridgian-Tithonian.

Crimea Mountains (Ukraine): The samples studied belong to the Yaila Series and come from the Aj-Petri and Jalta Yaila massifs. Short data on microfacies and the occurring algal-foraminiferan assemblage of the Yaila Series from Bilohirsk locality of the Crimea Peninsula have been provided by Granier et al. (2009). For these deposits, a Late Tithonian to Early Berriasian age can be deduced from the occurring benthic foraminifera (Granier and Bucur, 2010). For further information on the geology of the Crimea Mountains, especially the Late Jurassic-Early Cretaceous shallow-water carbonates, reference is made to Krajewski (2008) and Krajewski and Olszewska (2007). Chinianella? scheympflugi occurs in grain- to packstones, with thalli either showing a micritic envelope of variable thickness or a thin crust of light-brownish ooidal laminae (P1. I).

\section{MICROPALAEONTOLOGICAL DESCRIPTION} 1993.

\section{Genus Chinianella OTT ex GRANIER \& DELOFFRE,}

Remarks: The genus Chinianella was invalidly established by Ott (1967) and reinstated by Granier et al. (1994) with five Late Triassic, one Liassic, one Late Jurassic (= Ch.? scheympflugi) and one Lower Cretaceous species. The emended diagnosis has been given by Granier et al. (1994, p. 132) as follows: "cylindrical main axis bearing alternating fertile and sterile whorls; number of branches might vary from one type of whorl to the other (there are commonly more sterile branches than fertile ones in their respective whorls); calcified fertile branches consisting of inflated primary branches bearing small secondaries ending by open pores; calcified sterile branches rather thin with at least one order of branches". The uncertainty of the occurrence of the secondaries arising at the distal part of the primaries was the reason for Hofmann (1994) to put a question mark behind the generic assignment.

Chinianella scheympflugi HOFMANN (P1. I-II, Fig. 2)

1994 Chinianella (?) scheympflugi, n. sp. - Hofmann, Pl.

1, Figs. 1-4, Late Tithonian of Austria (Ernstbrunn Limestone).

1995 ?Heteroporella morillonensis BERNIER - Carras, Pl. 31, Fig. 1., Late Tithonian of Greece (see Fig. 2).

1999 Chinianella? scheympflugi HOFMANN Moshammer \& Schlagintweit, P1. 1, Figs. 1, 2, Late Tithonian or Earliest Berriasian of Austria (Ernstbrunn Limestone).

2005 Otternstella sp. - Bucur, Hoffmann \& Kolodziej, P1. 2, Figs. 5-6, 9, 13, Late Tithonian or Earliest Berriasian of Poland.

2005 Chinianella? sp. - Schlagintweit, Pl. 3, Fig. 10, Kimmeridgian or Tithonian of Austria.

Emended diagnosis: Based on the present results, the species diagnosis of Hofmann (1994, p. 144) is supplemented by the following sentences: Basal part of the thallus represented by a well-marked stalk bearing only sterile alternating phloiophorous laterals. In the main thallus portion, laterals are arranged one above the other forming vertical longitudinal rows.

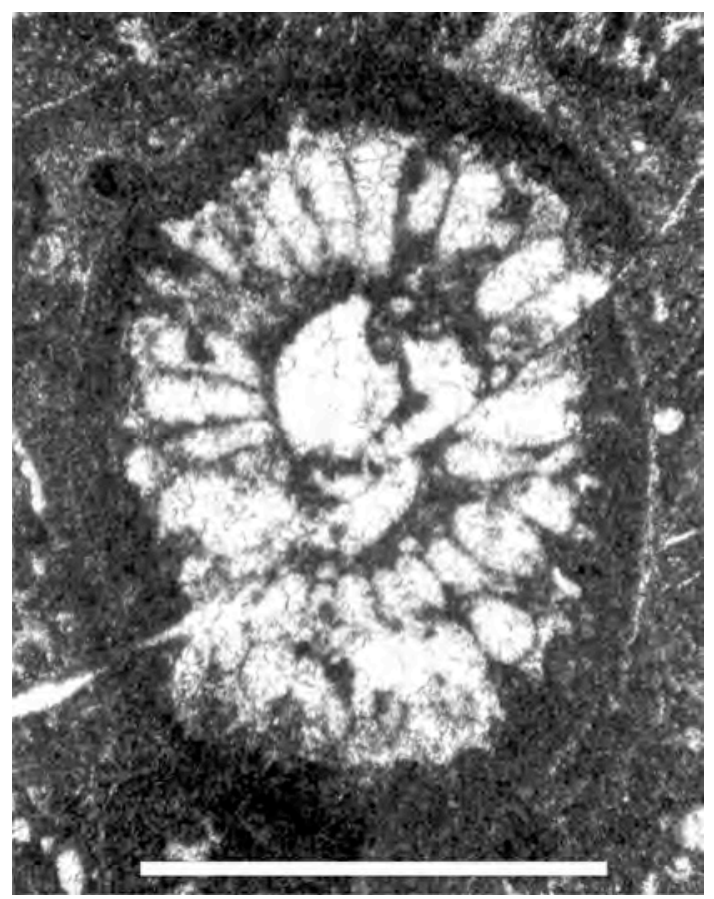

Fig. 2. Oblique section of Chinianella scheympflugi HOFMANN from the Late Tithonian of the Parnassos Zone/Greece (Carras, 1995; Pl. 31, Fig. 1, figured as ?Heteroporella morillonensis BERNIER); scale bar is $1.0 \mathrm{~mm}$.

Description: The thallus is composed of three parts: basal part, main part and top part.

The stalk shown in Fig. 3 is roughly cylindrical and shows a preserved length of $\sim 2.2 \mathrm{~mm}$, almost twice the outer thallus diameter of the main portion. The dimensional relationships of the total length of the main portion to the basal stalk, cannot be given as the only section showing this transition is incomplete. The transition to the main portion is rather abrupt; the diameter increases more than $20 \%$. Due to the cylindrical shape of the main thallus portion, the terminus "head" (e.g., Sokač, 2004) is avoided as it would implicate another overall morphology, such as club-shaped for instance. Within the stalk, only sterile laterals presumably with a distal widening (phloiophorous type; Salpingoporella-like), are present slightly bending during their length and alternating in position between successive whorls. With the abrupt morphological transition from the stalk to the main portion, the transition from the Salpingoporella-type to the Chinianella-type arrangement and form of laterals takes place between two successive whorls without any kind of transitional zone (see Fig. 3).

The rather short top part of the cylindrical medium-sized thallus is slightly tapering with a rounded end. At the part where the laterals change their direction from being arranged perpendicular to the longitudinal axis towards a radial orientation, only slightly bended sterile laterals are present as is well discernible in the holotype specimen of Hofmann (1994; P1. 1, Fig. 1, above). Approaching the top part, the fertile laterals reduce their diameter, thus getting less inflated. The top part of the thallus is well discernible in the longitudinal section of the holotype specimen (Hofmann, 
1994; P1. 1, Fig. 1). At the topmost part only sterile laterals are present.

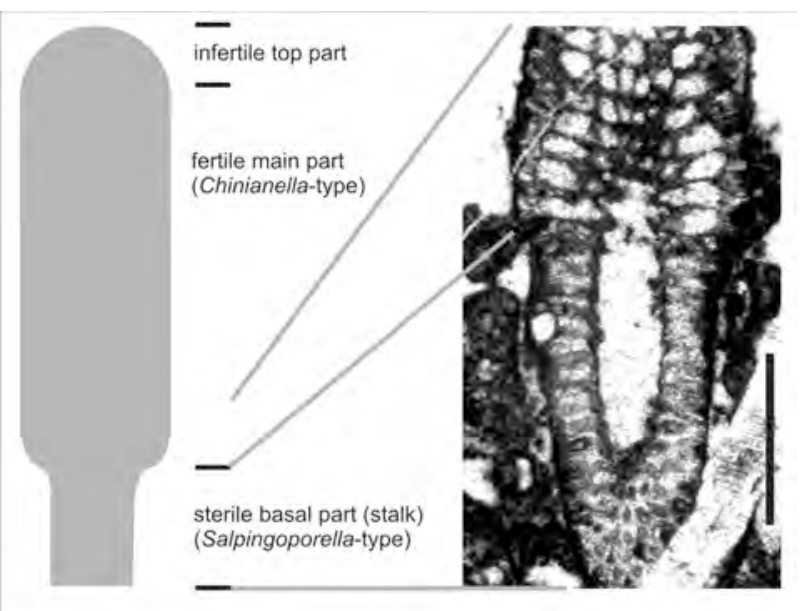

Fig. 3. Schematic tripartite thallus morphology of Chinianella scheympflugi HOFMANN, without scale (left); on the right a specimen from the Kimmeridgian Plassen Carbonate Platform of Mount Rettenstein (sample Rö 92) showing the fertile basal stalk with simple bended laterals, homeomorph to Salpingoporella pygmaea (GÜMBEL) and the abrupt transition to the main thallus portion displaying the Chinianella-type arrangement of laterals. The grey line marks the assumed portion of a complete thallus as shown on the left side. Scale bar is $1.0 \mathrm{~mm}$.
The main part of the thallus is represented by a cylindrical part. The outer thallus surface is always covered by a micritic coating of variable thickness or some ooidal laminae. The width of the smooth axial cavity is rather variable occupying about $17-41 \%$ of the total diameter. More often, however, it is in a rather narrow range between $\sim 22$ to $26 \%$. Along the thallus, whorls with either only fertile or only sterile laterals are regularly alternating. The arrangement of the laterals to the main axis is perpendicular or slightly tilted. They are closely packed together, mostly touching each others, thus, the calcareous partitions between laterals and verticils become rather thin. The fertile laterals are connected to the main axis by a short stalk, their general shape is variable from elongated pyriform (length/width ratio up to 3.5) (e.g., P1. I, Fig. 5) to roughly egg-shaped (length/width ratio up to 1.2) (e.g., Pl. I, Fig. 4). They are close set within a whorl. At their distal part, the fertile laterals may be rounded or, what Hofmann (1994) considered being species-characteristic, sharply bent, and bear secondary laterals. The laterals do no not alternate in position in consecutive whorls, but are arranged one above the other forming vertical longitudinal rows as is well discernible in the longitudinal-tangential section of Hofmann (1994; P1. 1, Fig. 1). These rows may slightly undulate (compare also with P1. I, Fig. 3).

Dimensions: See Table 1.

Table 1. Dimensions (in mm, except d/D) of Chinianella scheympflugi HOFMANN from the type-locality compared to those obtained from other regions (Greece, Ukraine, Austria).

\begin{tabular}{|l|c|c|c|c|c|c|c|c|}
\hline Location & $\mathbf{D}$ & $\mathbf{d}$ & $\mathbf{d} / \mathbf{D}$ & $\mathbf{h}$ & $\mathbf{w}$ & $\mathbf{w}$ & $\mathbf{l}$ & $\mathbf{p}$ \\
\hline $\begin{array}{l}\text { Ernstbrunn Limestone } \\
\text { Austria } \\
\text { (Hofmann, 1994) }\end{array}$ & $\begin{array}{c}0.6-0.89 \\
(0.72)\end{array}$ & $\begin{array}{c}0.09-0.19 \\
(0.14)\end{array}$ & $\begin{array}{c}0.14-0.25 \\
(0.19)\end{array}$ & $0.16-018$ & $10-12$ & $3-4$ & $\begin{array}{c}0.24-0.34 \\
(0.3)\end{array}$ & $\begin{array}{c}0.12-0.15 \\
(0.136)\end{array}$ \\
\hline $\begin{array}{l}\text { Parnassos Zone } \\
\text { Greece (Carras, 1995) }\end{array}$ & 1.145 & 0.33 & 0.29 & - & $24-35$ & & 0.114 & $0.07-0.15$ \\
\hline Crimea (this work) & $\begin{array}{c}0.58-1.13 \\
(0.88)\end{array}$ & $\begin{array}{c}0.17-0.26 \\
(0.22)\end{array}$ & $\begin{array}{c}0.21-0.38 \\
(0.245)\end{array}$ & $0.23-0.265$ & $10-26$ & & $0.16-0.37$ & $0.09-0.19$ \\
\hline $\begin{array}{l}\text { Plassen Carbonate } \\
\text { Platform Austria } \\
\text { this work) }\end{array}$ & $\begin{array}{c}0.57-1.3 \\
(0.91)\end{array}$ & $\begin{array}{c}0.22-0.4 \\
(0.28)\end{array}$ & $\begin{array}{c}0.2-0.41 \\
(0.32)\end{array}$ & 0.17 & $12-22$ & & $0.17-0.41$ & $0.08-0.17$ \\
\hline Total Range & $0.57-1.3$ & $0.09-0.4$ & $0.14-0.41$ & $0.16-0.265$ & $10-26$ & $3-4$ & $0.114-0.41$ & $0.08-0.19$ \\
\hline
\end{tabular}

Remarks: The dimensional data obtained from the Crimean and Alpine material shows a rather wide intraspecific biometric variability (compare data indicated by Hofmann, 1994), also of parameter ranges often used to discriminate different species. In this case, however, differences of maximum or minimum values of certain parameters differing more than $100 \%$ to the equivalent data given by Hofmann (1994) are still within the range of the same species. Emphasize is made to the variability of the $\mathrm{d} / \mathrm{D}$ ratio and also the shape of the laterals (here: fertile ones) accounting for the number (w) that could accommodate within one horizontal plane, respectively. The number of laterals within a whorl depends (beside the general size of the specimen) on the morphology of the primaries: much higher (more than twice) with elongated, club-shaped laterals compared to a whorl bearing highly inflated, egg-shaped laterals. It is noteworthy, however, that there is not a gap between the data of Hofmann (1994) and those from the present study displaying an overlapping common range. The wide morphological variability of the fertile laterals is also well discernible in the original figurations (Hofmann, 1994; Pl. 1, Fig. 1 vs Pl. 1, Fig. 2).

The detection of secondary laterals at the distal end of the inflated primaries allows the reinstatement of its original generic assignment so that the question mark can be put aside. The presence of short secondaries at the distal part of the sterile laterals is doubtfully presented in the work of Hofmann (1994), and could not be verified in the present study. This, however, is of no importance concerning the generic assignment because this feature is variable (presence or absence) in the genus diagnosis (see above).

Some general remarks on the basal portion of Dasycladales: Chinianella scheympflugi belongs to the group of Dasycladales with stalked thalli (e.g., Berger and Kaever 1992, p. 11-12). For these forms (and others) it is well known that the basal portion only bears sterile laterals, e.g. see reconstruction of living Cymopolia paktia in Berger and Kaever (1992; Fig. 2.10a). In most forms, also the top or apical part of the thallus lacks fertile laterals (e.g., Berger and Kaever, 1992; Fig. 3.31, for Neomeris). In the thallus reconstructions of fossil dasycladaleans, it has become general consensus to assume both a sterile basal and sterile top part (e.g., De Castro, 1997; Fig. 1). However, only in some cases these characteristics could be demonstrated in complete specimens. From the Lower Cretaceous of Iran, Taherpour Khalil Abad et al. (2010) illustrated and described a $7 \mathrm{~mm}$ long complete cylindrical thallus of Montiella? elitzae (BAKALOVA). It shows a more narrow 
basal part, which cannot be really termed a stalk, which lacks fertile gametophores. The tip of the section is shown to be fertile and the authors (op. cit., p. 7) assume that the "uncalcified sterile vertex of the alga decayed before the vegetative phase ended, prior to the formation of gametophores". With gametophores attached laterally to the primaries, M.? elitzae corresponds to the group of choristospore Dasycladales. Another example, also from the Lower Cretaceous, is Cylindroporella ivanovici (SOKAČ), a taxon with controverse systematic assignment (see short review in Bucur et al., 2008; Sokač, $2004=$ Korkyrella ivanovici). This controversy, however, is not of importance for the purpose of the present paper as we are here only referring to the basal part of the thallus; the different views mainly concern the fertile thallus portion with the details on number, form, and arrangement of the laterals. The reconstruction of the alga presented by Sokač (2004; Fig. 3) shows phloiophorous primaries alternating in position between successive whorls, that is to say an arrangement typical for the genus Salpingoporella. A detailed reconstruction of Salpingoporella? popgrigorei (Lower Cretaceous of Romania) has been provided by Bucur (2007). In the middle, fertile main portion of the thallus, the phloiophorous laterals display a pronounced swelling in the middle part, where the reproductive structures (cysts) were most likely located. In the basal portion of reduced thallus diameter, the laterals are shorter and narrow flattened, lacking the swelling. A similar situation is assumed for the tapering topmost part of the thallus. With the morphology designated as club-shaped, the belonging to the genus Salpingoporella was questioned by Bucur (2007). In my opinion, the thallus shape is simple cylindrical (main part), with a tapering rounded top and a basal part where the outer diameter simply decreases. Such a widespread morphology is taken as the general reconstructional type for many Paleogene Dasycladales, recently presented by Génot (2009). Hence, there is not need to attribute this character that seems to be the basic morphology for "cylindrical" (=rod-shaped of Berger and Kaever, 1992; Fig. 2.2a) dasycladalean algae, as criterion of generic importance.

Whereas in the example Montiella? elitzae with a gradual widening from the basal part to the main portion, the sterile stalk of Cylindroporella? ivanovici passes rather abruptly into the upper part ("head" of Sokač, 2004) comparable to Chinianella scheympflugi. From this observation arises the general question what can be taken as boundary for a stalk and just a simple continuous decrease of the thallus diameter towards its base? With respect to the stalk of $C h$. scheympflugi two main aspects should be emphasized. First, the sterile laterals are alternating between successive whorls, whereas in the main portion the fertile laterals are arranged more or less in contiguity one above the other along the thallus. The second aspect is, that the general appearance of the stalk is homeomorph to the dasycladale Salpingoporella pygmaea (GÜMBEL), a species often co-occurring with $C h$. scheympflugi. As the stalk is often broken away, unambiguous determination then becomes problematic also because of the wide range of the biometric data of Salpingoporella pygmaea (GÜMBEL) (see Carras et al., 2006; Tab. 5) fitting those from the stalk of $C h$. scheympflugi. In the example of Salpingoporella popgrigorei BUCUR the aspect of the laterals is "salpingoporelliform" throughout the complete thallus. In Studia UBB Geologia, 2011, 56 (1), 3 - 9
Chinianella scheympflugi and also Cylindroporella? ivanovici the type and arrangement of the laterals in the stalk and main portion are completely different.

From a stratigraphic point of view, Ch. scheympflugi could be integrated in the list of taxa that could perhaps be of importance for the location of the Jurassic-Cretaceous boundary in carbonatic shallow-water regimes (see short summary in Granier and Bucur, 2010). The evidenced Kimmeridgian-Tithonian range can be taken for sure, but its occurrence in the Early Berriasian is not proven and can therefore not be excluded.

Acknowledgements. Thin-sections from the Northern Calcareous Alps were kindly provided by Hans-Jürgen Gawlick, Sigrid Missoni and Matthias Auer (University of Leoben). Photographs from the Crimean material, provided by Marcin Krajewski (Kraków), were made and contributed by Ioan I. Bucur ("Babeş-Bolyai" University). Nicolaos Carras (Athens) is thanked for providing the photograph shown in Fig. 2 and the permission for re-illustration. Marc Conrad (Perly) and Ioan I. Bucur (Cluj-Napoca) are thanked for helpful remarks.

\section{R E F E R E N C E S}

Auer, M., Suzuki, S., Schlagintweit, F. \& Gawlick, H.-J. 2009, Spatial and temporal development of siliceous basin and shallow-water carbonate sedimentation in Oxfordian Northern Calcareous Alps. Facies, 55: 63-87; DOI: http://dx.doi.org/10.1007/s10347-008-0155-3

Bachmayer, F. 1941, Zwei neue Siphoneae verticillatae aus dem Jurakalk von Dörfles und Klafterbrunn (NiederDonau). Verhandlungen der zoologisch-botanischen Gesellschaft in Wien, LXXXX/LXXXXI: 237-240.

Berger, S., Kaever, M.J. 1992, Dasycladales. An illustrated monograph of a fascinating algal order. Thieme Stuttgart, $247 \mathrm{p}$.

Bucur, I.I. 2007, Salpingoporella? popgrigorei, a new species of Dasycladales (calcareous algae) from the Lower Aptian deposits of Pădurea Craiului (northern Apuseni Mountains, Romania). Facies, 53 (3): 377-388; DOI: http://dx.doi.org/10.1007/s10347-007-0113-5

Bucur, I.I., Granier, B. \& Săsăran, E. 2008, Upper Aptian calcareous algae from Pădurea Craiului (Northern Apuseni Mountains, Romania). Geologia Croatica, 61 (2-3): 297-309.

Bucur, I.I., Hoffmann, M. \& Kolodziej, B. 2005, Upper Jurassic-Lowermost Cretaceous benthic algae from Tethys and the European platform: a case study from Poland. Revista Espanola de Micropaleontologia, 37 (1): 105-129.

Carras, N., Conrad, M.A. \& Radoičić, R. 2006, Salpingoporella, a common genus of Mesozoic Dasycladales (calcareous green algae). Revue de Paléobiologie, 25 (2): 457-517.

Carras, N. 1995, La piattaforma carbonatica del Parnasso durante il Guirassico Superiore - Cretaceo inferiore. Desp. Mavromatis Edition, Athens, 232 p. (in Greek with Italian abstract).

De Castro, P. 1997, Introduzione allo studio in sezione sottile delle dasicladali fossili. Quaderni dell' Accademia Pontaniana, 22: 1-137.

Dya, M. 1992, Mikropaläontologische und fazielle Untersuchungen im Oberjura zwischen Salzburg und 
Lofer. Unpublished $\mathrm{PhD}$ thesis, Technical University of Berlin, 1-137.

Gawlick, H.-J., Missoni, S., Schlagintweit, F., Suzuki, H., Frisch, W., Krystyn, L. \& Lein, R. 2009, Jurassic Tectonostratigraphy of the Austroalpine Domain. Journal of Alpine Geology, 50: 1-152.

Génot, B. 2009, Cenozoic Dasycladales - A photo-atlas of Lutetian species from French Cenozoic Basins. Carnets de Géologie Special publication, 1.

Granier, B., Bucur, I.I. 2010, Stratigraphic ranges of some Tithonian-Berriasian benthic foraminifers and Dasycladales. Re-evaluation of their use inidentifying this stage boundary in carbonate platform settings. In Platform to basin correlations in Cretaceous times (Grosheny, D., Granier, B. \& Sanders, N., Eds.). Boletín del Instituto de Fisiografía y Geología, 79-80: 2 p.

Granier, B., Bucur, I.I., Krajewski, M. \& Schlagintweit, F. 2009, Calcareous algae from the Yaila Series near Bilohirsk (Crimea, Ukraine). In IFAA $6^{\text {th }}$ Regional Symposium. Abstracts and Field Trip Guide Book (Basso, D., Caragnano, A., Bracchi, V. \& Benzoni, F., Eds.). Annali dell' Università degli Studi di Ferrara, Spec. vol., p. 30.

Granier, B., Masse J.-P. \& Berthou, P.-Y. 1994, Heteroporella lepina PRATURLON, 1967, revisited (followed by taxonomic notes on the so-called "Heteroporella" species). Beiträge zur Paläontologie, 19: 129-141.

Hofmann, T. 1994, Chinianella (?) scheympflugi, a new Dasyclad alga (green algae) from the Tithonian Ernstbrunn Limestone in Lower Austria. Beiträge zur Paläontologie, 19: 143-147.

Krajewski, M. 2008, Lithology of the Upper Jurassic-Lower Cretaceous (Tithonian-Lower Beriasian) Aj-Petri reefcomplex (southern Ukraine, the Crimea Mountains. Neues Jahrbuch für Geologie und Paläontologie, Abhandlungen, 249 (2): 239-255.

Krajewski, M., Olszewska, B. 2007, Foraminifera from the Late Jurassic and Early Cretaceous carbonate platform facies of the southern part of the Crimea Mountains; southern Ukraine. Annales Societatis Geologorum Poloniae, 77: 291-311.
Missoni, S., Schlagintweit, F., Suzuki, H. \& Gawlick, H.-J. 2001, Die oberjurassische Karbonatplattformentwicklung im Bereich der Berchtesgadener Kalkalpen (Deutschland) - eine Rekonstruktion auf der Basis von Untersuchungen polymikter Brekzienkörper in pelagischen Kieselsedimenten (Sillenkopf-Formation). Zentralblatt für Geologie und Paläontologie, 1 (2): 117-143.

Moshammer, B., Schlagintweit, F. 1999, The Ernstbrunn Limestone (Lower Austria): New data on Biostratigraphy and Applied Geology. Abhandlungen der Geologischen Bundesanstalt Wien, 56 (2): 553-565.

Ott, E. 1967, Dasycladaceen (Kalkalgen) aus der nordalpinen Obertrias. Mitteilungen der Bayerischen Staatssammlung für Paläontologie und historische Geologie, 8: 253-262.

Schlagintweit, F. 2005, Neogyroporella? gawlicki n. sp., a new Dasycladale from the Upper Jurassic-Lower Cretaceous "Lärchberg Formation" of the Northern Calcareous Alps. Geologia Croatica, 58 (2): 1-15.

Schlagintweit, F., Gawlick, H.-J. \& Lein, R. 2005, Mikropaläontologie und Biostratigraphie der PlassenKarbonatplattform der Typlokalität (Ober-Jura bis Unter-Kreide, Salzkammergut, Österreich). Journal of Alpine Geology, 47:11-102.

Sokač, B. 2004, On some peri-mediterranean Lower Cretaceous Dasyclad species (Calcareous algae; Dasycladales) previously assigned to different genera. Geologia Croatia, 57 (1): 15-53.

Taherpour Khalil Abad, M., Conrad, M.A., Aryaei, A.A. \& Ashouri, A.R. 2010, Barremian-Aptian dasycladalean algae, new and revisited, from the Tigran Formation in the Kopet Dagh, NE Iran. Carnets de Géologie, Article 2010/05 (CG2010_A05). 

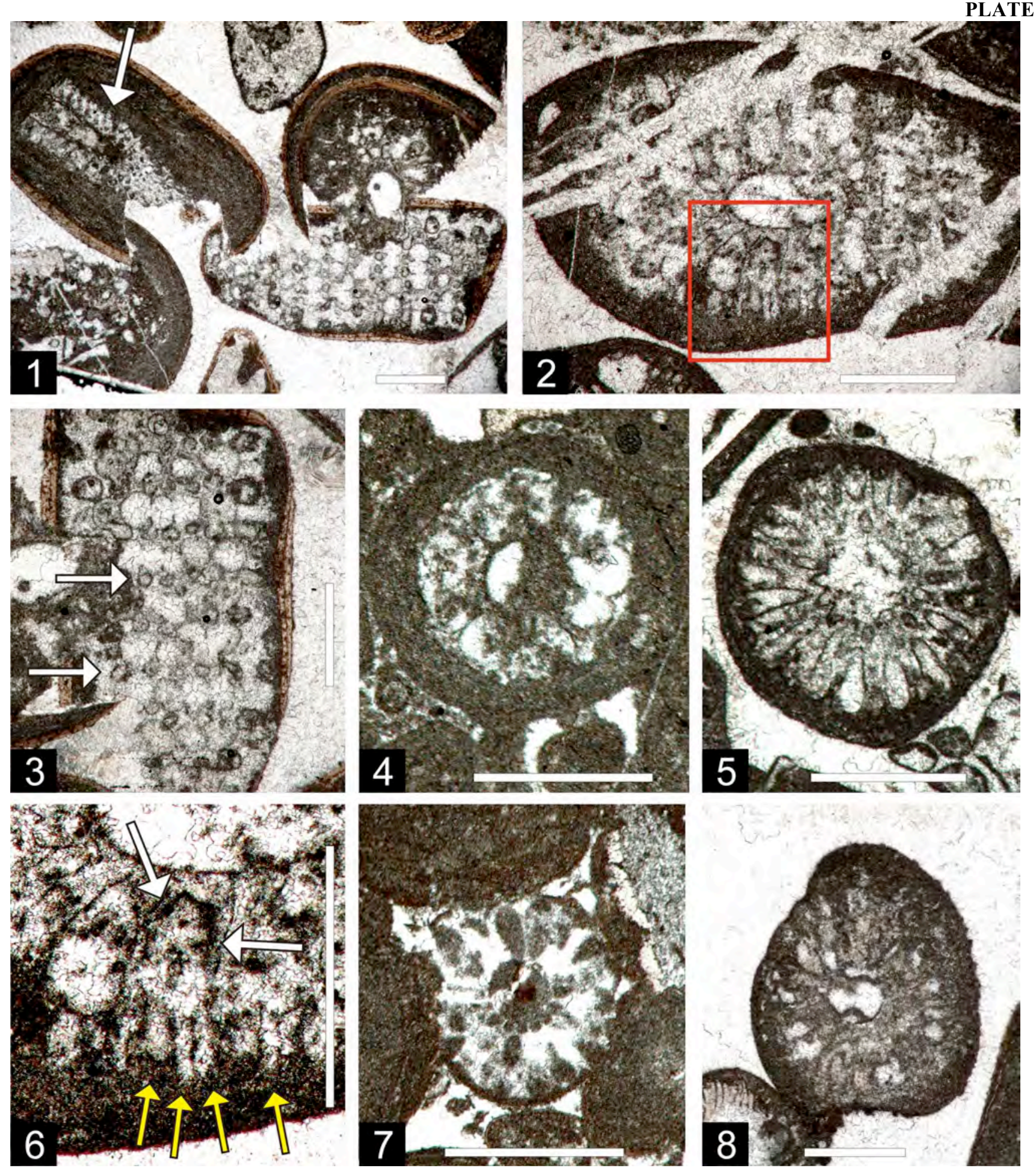

Plate 1. Chinianella scheympflugi HOFMANN from the Late Tithonian (?Early Berriasian) of Crimea Mountains/Ukraine.

Fig. 1. Grainstone with various specimens coated by thin ooidal laminae. Oblique longitudinal section (arrow) on the left could belong to a sterile stalk of Chinianella scheympflugi or Salpingoporella pygmaea (GÜMBEL) (compare Text-Figure 3), a species that might co-occur with the former (Thin section KC-27; scale bar is $0.5 \mathrm{~mm}$ ).

Fig. 2. Oblique section. The red rectangle marks the detailed view shown in Fig. 6 (Thin section KB-15c; scale bar is $0.5 \mathrm{~mm}$ ).

Fig. 3. Detail from Fig. 1, longitudinal-tangential section displaying the alternation of planes with thin sterile and inflated fertile laterals (arrows) (Thin section KC-27; scale bar is $0.5 \mathrm{~mm}$ ).

Figs. 4, 5. Transverse sections; note the variable shape of the fertile laterals being egg-shaped in Fig. 4, and inflated pyriform in Fig. 5. The morphological difference also accounts for the number of laterals (w) that could accommodate in one vertical plane, about 10 in Fig. 4 and more than 20 in Fig. 5. Note furthermore the thick micritic coating of the thalli (Thin sections KE-12 and KC-11; scale bars are $0.5 \mathrm{~mm}$ ).

Fig. 6. Detail from Fig. 2 showing sterile laterals between fertile ampullae (white arrows above) and short secondaries arising at the upper side of the ampullae (yellow arrows below) (Thin section KC-27; scale bar is $0.5 \mathrm{~mm}$ ).

Fig. 7. Slightly oblique transverse section (Thin section KJ-5a; scale bar is $0.5 \mathrm{~mm}$ ).

Fig. 8. Oblique section, noting the very low d/D ratio in comparison to Figs. 4-5 showing the biometric thallus variability (Thin section KC27; scale bar is $0.5 \mathrm{~mm}$ ).

Studia UBB Geologia, 2011, 56 (1), 3 - 9 

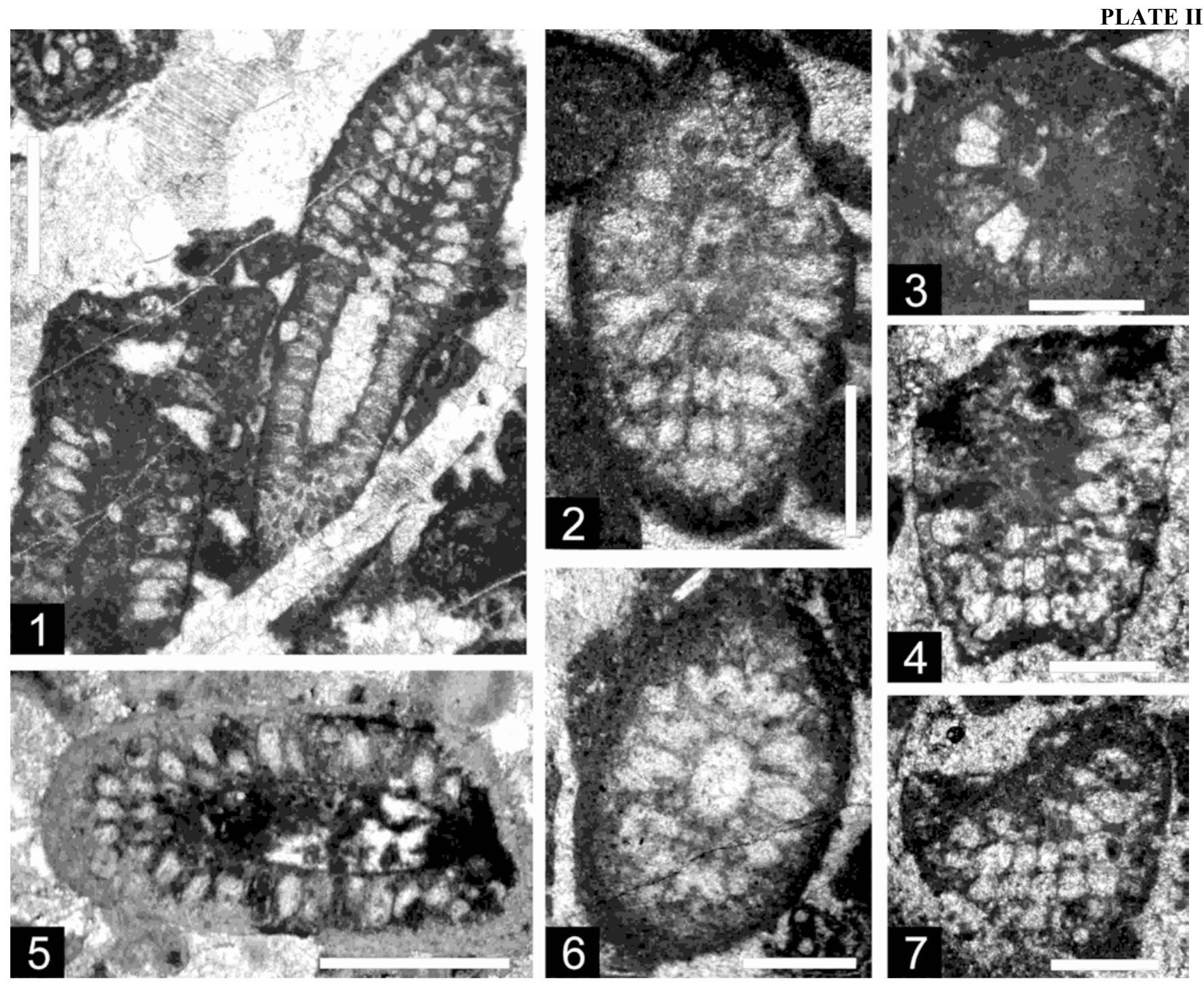

Plate 2. Chinianella scheympflugi HOFMANN from the Kimmeridgian-Tithonian of the Plassen Carbonate Platform of Austria.

Fig. 1. Microfacies with two sections. Note the elongated inflated fertile laterals compared to specimens with more pyriform shape, e.g. Pl. I, Fig. 4. The specimen on the right shows the preserved transition from the stalk to the main portion (see also Text - Fig. 3). (Mount Rettenstein; thin section Rö 92; scale bar is $1.0 \mathrm{~mm}$ ).

Fig. 2. Oblique section; note the linear arrangement of the fertile laterals between successive whorls below (Mount Lärchberghörndl; thin section KS 71; scale bar is $0.5 \mathrm{~mm}$ ).

Fig. 3. Strongly micritized transverse section; number of laterals $\sim 23$ to 25 (Mount Lärchberghörndl; thin section KS 71 ; scale bar is 0.5 $\mathrm{mm})$.

Fig. 4. Oblique section (Mount Rettenstein; thin section Rö 348; scale bar is $0.5 \mathrm{~mm}$ ).

Fig. 5. Oblique section; note the comparable wide main axis with respect to outer thallus diameter (Mount Sillenköpfe; thin section Ber 51-5; scale bars are $0.5 \mathrm{~mm}$ ).

Fig. 6. Oblique section. (Mount Plassen; thin section PL 70d; scale bar is $0.5 \mathrm{~mm}$ ).

Fig. 7. Tangential oblique section (Mount Rettenstein; thin section Rö 334; scale bar is $0.5 \mathrm{~mm}$ ). 